\title{
The Evolution of Diversity Climate Research: A Review and Synthesis
}

\author{
Hazal Koray Alay1 $\odot$, Esin Can² $\odot$
}

\begin{abstract}
The purpose of this paper is to integrate the results obtained from various studies on the diversity climate.The academic development of the concept of diversity climate in work life has been analyzed in a comprehensive way. Forty-one empirical studies published between 1975 and 2018 were retrieved from the ISI Web of Knowledge database and included in this theory-driven review. The main research questions of the current study are the following: "What do we know about the diversity climate in organizations? What theories is diversity climate based on? What is the focal point of the diversity climate? What are the dimensions and outcomes of diversity climate?". The result suggests that the holistic picture about the diversity climate theories, variables, research method, unit of analysis and results of the articles reviewed.This research helps to identify diversity climate which is important for the graduate students, researchers and scholars who are interested or working in the field of diversity and diversity climate..
\end{abstract}

\section{Keywords}

Diversity climate at workplace, Demographic minorities, Identity structure, Theory-driven review, Synthesiss

\section{Introduction}

Diversity is an inevitable phenomenon that exists in human nature. People have different perspectives, values, beliefs, cultural backgrounds, physical and mental characteristics. However, it is difficult for societies and organizations to see all these differences as valuable. This occurs only by help of some driving forces that change organizations and societies in various ways. Globalization, mergers, international agreements, legal obligations, change in demographic structures and differentiation of the work force are among these driving forces. People's characteristics and abilities are different, similar how each snowflake is different

\footnotetext{
1 Corresponding author: Hazal Koray Alay (PhD.), Yıldız Technical University, Social Sciences Institute, Departmant of Business Management, Istanbul, Turkey. E-mail: hazalkoraygenc@hotmail.com ORCID: 0000-0002-6638-3089

2 Esin Can (Prof. Dr.), Yıldız Technical University, Faculty of Economics and Administrative Sciences, Departmant of Business Management, Istanbul, Turkey. E-mail: esincan @yildiz.edu.tr ORCID: 0000-0003-1754-4867

To cite this article: Koray-Alay, H., \& Can, E. (2020). The evolution of diversity climate research: A review and synthesis. Istanbul Business Research, 49(1), 36-59. http://doi.org/10.26650/ibr.2020.49.0022
} 
from one another. Those who want to benefit from the advantages that may come with these differences should learn to manage them. In this context, diversity management points to an understanding of balancing the tension arising from employee differences and trying to gain an advantage from these differences. Another important topic related to diversity management is diversity climate. Diversity climate is defined as perception of the opportunities and obstacles created by organizations against those who are considered different within organizations (Kossek and Zonia, 1993). The diversity climate is an organizational atmosphere that is influenced by many factors and situations which also affects many situations at the individual and organizational level.

The first study on diversity climate was made by Kossek and Zonia (1993). Their purpose was to determine what the organizations do to increase the representation of women and minority groups. Another important study for the diversity climate was made by Mor Barak et al. (1998). They developed a scale (Diversity Perception Scale) to evaluate the perception of organizational justice and inclusion in organizations. Diversity Perception Scale assesses the extent of anorganization's support for the diversities.The first study on the minority groups indiversity climate (Kossek and Zonia, 1993) and the Diversity Perception Scale (Mor Barak et al. 1998) increased the awareness about this subject and became the pioneer for further researches.

According to George Herbert Mead's symbolic interaction theory, individuals attribute a meaning to the organization based on their social interactions within the organization (Aksan et al. 2009). The meaning attributed to the organization held perception of organizational climate. In this context, diversity climate is a metaphoric organizational atmosphere that explains the interaction of minorities with other employees within the organization. Individual, group and organization level interactions occur in various negative ways such as prejudice, stereotype, conflict, discrimination, exclusion (Roberson, Ryan and Ragins, 2017) and positive ways such as support for diversity and inclusiveness. According to Chin (2009), the diversity climate of an organization reflects the common perceptions of the employees towards various diversity related workplace harassment and discrimination behaviors. Another similar definition, diversity climate is perceptions about the practices in places where there is no discrimination and where the differences are supported (Hardeman et al. 2016). Some organizations develop policies, rules and practices according to employees' perceptions, attitudes and behaviors, while others only pay regard to their own interests. However, each employee develops various attitudes and behaviors towards the practices within the organization, which directly or indirectly affect themselves and other employees. In a sense, diversity climate is defined asthe perceptions of the opportunities and obstacles created by the organization against diversity.

The term "Diversity Climate" has first appeared in the 1990s. It has received a steady and increasing interest by organizations, business world and scholars. Demographic diversity is 
in all areas of working life. Therefore, it has been the subject of many different disciplines. Recently, it has become the focus of management and organizational behavior principles. However, it cannot be said that the mechanisms and outcomes of diversity climate in the workplace are fully understood. Accordingly, the purpose of this study is to examine the diversity climate phenomenon. Thus, the paper will try to fill the gap in the literature by conducting a theory-driven review of empirical research in diversity climate.

The following steps were followed to reach the purpose of the research:

- Development of research methodology

- Scanning of the relevant electronic database

- Searching for answers to research questions

- Synthesis of diversity climate studies

However, our research has some limitations. Firstly, articles written in English between a specific date range (1975-2018) were chosen from the Web of Knowledge electronic database. Then, the articles on the diversity climate were searched. As shown in Table 1, 41 articles were included in the study.

Table 1

Result of the Electronic Database Search

\begin{tabular}{cccc}
\hline $\begin{array}{c}\text { Name of the Electronic } \\
\text { Database }\end{array}$ & Key Terms of Searched in & Additional Limitations & Number of Articles Found \\
\hline Web of Knowledge & Title & $\begin{array}{c}1975-2018+\text { Article+Engilish } \\
\text { Language }\end{array}$ & 41 \\
\hline
\end{tabular}

This research examined the theories, variables, research method, unit of analysis and results of the articles reviewed. It contributes to the research on diversity climate in organization. Firstly, it undertakes a role as an objective exaaminer view of diversity has been perceived in time. Secondly, it provides a review of the variables affecting the perception of diversity climate in organizations by combining existing studies on diversity climate. Thirdly, it contributes to the knowledge regarding cognitive, motivational and behavioral outcomes of diversity climate. Finally, reseacrh results suggest that holistic model of diversity climate for future work. It is expected that the valuation will contribute to a better understanding of diversity climate.

\section{Review of the Diversity Climate Literature}

While the subject of this research was being chosen, it was paid attention whether the number of previous studies was sufficient or not. This has importance in terms of the significance of the synthesis to be made. Thus, a structured literature review was performed 
using the ISI Web of Knowledge database. A hundered and fifty two articles published between 1975-2018 were found with the selected keyword "diversity climate". Articles that focus on biodiversity, atmospheric climate, or not focusing on an organizational context were excluded from the research. Research areas reviewed for the article are given in Table 2:

Table 2

List of Research Areas with the Publications

\begin{tabular}{cc}
\hline Name of the research areas & Number of the publishings \\
\hline Management & 25 \\
Psychology & 17 \\
Business & 10 \\
Ethics & 2 \\
Social Psychology & 2 \\
Developmental Pschology & 2 \\
\hline
\end{tabular}

Forty one articles were included in the research after evaluating their eligibility and relevance criteria. Research methods of these articles were: qualitative (37), quantitative (3), meta analysis (1). Unit of analysis of these studies were: the individuals.

The highest number was by researchers working in the USA. The number of studies made in the countries is as in the following Table 3 :

Table 3

List of the Countries with the Publications

\begin{tabular}{cc}
\hline Name of the countries & Number of the publishings \\
\hline USA & 33 \\
Netherlands & 5 \\
Germany & 2 \\
Taiwan & 2 \\
Italy & 1 \\
Israel & 1 \\
Dubai-United Arab Emirates & 1 \\
\hline
\end{tabular}

In Table 4 the number of articles are shown alongside the journal names. The journals that published the subject of diversity climate the most are; Personnel Psychology (5), Journal Of Organizational Behavior (2), Journal Of Applied Psychology (2), Human Resource Management (2), Equality Diversity And Inclusion (2), Journal Of Business Ethıcs (2). 
Table 4

List of the Publishing Journals about Diversity Climate

\begin{tabular}{|c|c|c|c|}
\hline Journal Title & $\begin{array}{c}\text { N. of } \\
\text { Articles }\end{array}$ & Journal Title & $\begin{array}{c}\text { N. of } \\
\text { Articles }\end{array}$ \\
\hline PERSONNEL PSYCHOLOGY & 5 & $\begin{array}{l}\text { ACADEMY OF MANAGEMENT } \\
\text { JOURNAL }\end{array}$ & 1 \\
\hline $\begin{array}{l}\text { JOURNAL OF ORGANIZATIONAL } \\
\text { BEHAVIOR }\end{array}$ & 2 & $\begin{array}{l}\text { JOURNAL OF MANAGERIAL } \\
\text { PSYCHOLOGY }\end{array}$ & 1 \\
\hline JOURNAL OF APPLIED PSYCHOLOGY & 2 & EUROPEAN MANAGEMENT REVIEW & 1 \\
\hline HUMAN RESOURCE MANAGEMENT & 2 & SEX ROLES & 1 \\
\hline EQUALITY DIVERSITY AND INCLUSION & 2 & $\begin{array}{l}\text { INTERNATIONAL JOURNAL OF } \\
\text { ORGANIZATIONAL ANALYSIS }\end{array}$ & 1 \\
\hline JOURNAL OF BUSINESS ETHICS & 2 & $\begin{array}{l}\text { JOURNAL OF OCCUPATIONAL HEALTH } \\
\text { PSYCHOLOGY }\end{array}$ & 1 \\
\hline INTERNATIONAL BUSINESS REVIEW & 1 & SPRINGERPLUS & 1 \\
\hline $\begin{array}{l}\text { JOURNAL OF GENERAL INTERNAL } \\
\text { MEDICINE }\end{array}$ & 1 & $\begin{array}{l}\text { INTERNATIONAL JOURNAL OF } \\
\text { CONTEMPORARY HOSPITALITY } \\
\text { MANAGEMENT }\end{array}$ & 1 \\
\hline $\begin{array}{l}\text { JOURNAL OF APPLIED SOCIAL } \\
\text { PSYCHOLOGY }\end{array}$ & 1 & $\begin{array}{l}\text { AFRICAN JOURNAL OF BUSINESS } \\
\text { MANAGEMENT }\end{array}$ & 1 \\
\hline ACADEMIC MEDICINE & 1 & $\begin{array}{l}\text { JOURNAL OF THE NATIONAL MEDICAL } \\
\text { ASSOCIATION }\end{array}$ & 1 \\
\hline CAREER DEVELOPMENT INTERNATIONAL & 1 & ORGANIZATION SCIENCE & 1 \\
\hline $\begin{array}{l}\text { INTERNATIONAL JOURNAL OF } \\
\text { HOSPITALITY MANAGEMENT }\end{array}$ & 1 & PUBLIC MANAGEMENT REVIEW & 1 \\
\hline CHILD DEVELOPMENT & 1 & JOURNAL OF VOCATIONAL BEHAVIOR & 1 \\
\hline JOURNAL OF MANAGEMENT & 1 & $\begin{array}{l}\text { INTERNATIONAL JOURNAL OF } \\
\text { INNOVATION MANAGEMENT }\end{array}$ & 1 \\
\hline JOURNAL OF BUSINESS AND PSYCHOLOGY & 1 & QUALITY \& QUANTITY & 1 \\
\hline CHILDREN AND YOUTH SERVICES REVIEW & 1 & $\begin{array}{l}\text { JOURNAL OF SERVICE THEORY AND } \\
\text { PRACTICE }\end{array}$ & 1 \\
\hline
\end{tabular}

Individual differences examined in the studies are; racioethnicity gender, age sexual orientation, tenure, income employment status, human resource practices, language, religion, team strain, workplace localization. The number of the studies made in individual differences are as in the following: 
Table 5

List of the Individual Diffrences

\begin{tabular}{lc}
\hline Name of the individual differences & Number of the studies \\
\hline Racioethnicity & 25 \\
Gender & 20 \\
Age & 7 \\
Sexual orientation & 4 \\
Tenure & 3 \\
Income & 2 \\
Employment status & 2 \\
Human resource practices & 1 \\
Language & 1 \\
Religion & 1 \\
Team strain & 1 \\
Workplace localization & 1 \\
\hline
\end{tabular}

As a result, it can be evaluated that race and gender are the most important individual differences used to measure the perception of diversity climate. Organizational commitment, job satisfaction, job motivation, burnout, stress level, perception of justice have been evaluated as individual outcomes. Turnover ratio, intent to quit, performance, conflict, leadership opennes to diversity, cohesion and communication, product innovation, human resource practice, firm effectiveness have been evaluated as organizational outcomes. Table 6 (Appendix 1) provides detailed information on the reviewed diversity climate studies.

\subsection{Definition of Diversity Climate}

Theory-driven review of empirical research examined that the definitions of the diversity climate vary according to the focal point used. However, the majority of the articles describe the diversity climate referring to Kossek and Zonia (1993)'s pioneering work. The basic assumption surrounding these diversity climate definitions is about what organizations do to increase the representation of minority groups, and to what extent they value and promote diversities. Other definitions of diversity climate refer to Mor Barak, Cherin and Berkman (1998)'s study which focus on to what extent an organization supports diversity in order to provide an inclusive and fair climate. Similarly, Kaplan et al. (2011) define diversity climate as the common perception of the employees regarding the justice policies, practices andequal participation encouragement. According to Gelfand et al. (2005) the diversity climate is the common perception of the employees in the organization where discrimination is prevented and diversity is supported.The main idea of these definitions is to focus on organizational sensitivity based on gender and ethnic identity and social integration of minorities.

The diversity climate has become more meaningful in Cox (1993)'s model that explains three different levels. These are: (1) individual level; (2) group and inter-group level; and (3) organizational level. At the individual level, the diversity climate is examined under four different 
factors: identity structures, prejudice and discrimination, stereotypes and prejudiced personality. The group and inter-group levels are examined under three factors: cultural differences among groups, ethnocentrism and intergroup conflict. Organizational level factors are examined under four factors: organizational culture and cultural interaction, structural integration, non-formal integration and corporate prejudice. According to Cox (1993), organizations that create a climate where all employees are supported and have equal opportunities succeed to reach a better position than their competitors. This also increases the number of more creative and motivated employees. Thereby, employees who are respected in the workplace and who are treated equally in terms of education, career and promotion increase the firm productivity and efficiency. In addition, it is stated that the loyalty and job satisfaction of the employees are also increased in the situation that their managers are against all kinds of discrimination (such as gender, race, ethnic origin, religion, language, disability status).

Analyzed articles mainly refer to social integration and representation of minorities about diversity climate. For example, while Hofhuis et al. (2012) emphasize "openness and encouragement for diversities", Lauring and Selmer $(2011,2012)$ draw attention to the issue of respecting and valuing the diversity of individuals. McKay et al. $(2007,2008,2011)$ indicate that the diversity climate gets nourished from cultural diversities and that these diversities affect individual and organizational outcomes. On the other hand, Chen et al. (2012) focus on equal access to opportunities, while Sliter et al. (2014) focus specifically on discrimination against women. According to Gonzalez and Denisi (2009), the diversity climate reflects the attitudes and behaviors based on perceptions towards employees with different characteristics (such as women, minorities). Another study draws attention to the distribution of resources and opportunities in organizations. Diversity climate can be explained based on the perception of justice that resources about employee development (such as technical support, obtaining permission, payments) and access to suitable positions for career progression (Herdman and McMillan, 2010; Boehm et al. 2014).

Overall, the main focus of these definitions correspond with the perspective of social cohesion, equal employment and discrimination.

\subsection{The Dominant Theoretical Lenses Underlying of Diversity Climate}

The main theories that have been determined from the 41 articles included in this study are; social identity theory, intergroup relations theory, intergroup contract theory, interactional model of cultural diversity, racial identity theory, social categorization theory, the signaling theory, equity theory, faultline theory, the resource-based theory. These theories are briefly explained below.

- Social identity theory: Social identity theory is one of the basic theories of social psychology that explain social categorization, social identification, social comparison. 
People have a tendency to split into groups and perceive their group superior to other groups. The reason for this is people's tendency to make positive self-evaluation. People achieve this positive self-evaluation by considering that the groups they are in superior and by identifying with them. At this point, the concept of social identity comes in sight. Social Identity Theory developed by Henri Tajfel and John Turner in the mid-1970s explains this concept in the most comprehensive way. Tajfel and Turner (1979), reveal the fact in their experiments called minimal group paradigm, that even artificial groups, which do not normally exist, are sufficient for people to favor their own groups and see them superior to others. (McKay et al. 2007, 2009; Price et al. 2005, 2009; Hofhuis et al. 2012, 2016; Buttner et al. 2009; Avery et al. 2013; Dwertmann et al. 2016; Brimhall et al. 2014; Randel et al. 2016; Madera et al.2016; Cole et al.2016; Buttner and Lowe 2017; Paolillo et al. 2017).

- Equity theory: Adams' Equity Theory (1963) is based on three main factors: contribution, acquisitionand reference. Theory suggests that employees compare their own gain / contribution ratio with that of others. Here, "other" is the individual referenced during the comparison. It can be someone from the work group, another employee in the organization, a person from the same branch or department. In short, it can be just about anyone for the individual to compare themselves to. However, it is seen that individuals prefer a person who is similar to them regarding some factors such as gender, seniority, status, education or specialization. According to the equity theory, employees desire an environment in which all employees are treated equally in the work environment and this desire has an impact on the employees' motivation. It is known that perceived wage inequality significantly affects variables such as job satisfaction, emotional organizational commitment, absenteeism and intention to quit (Goby et al. 2015; Buttner and Lowe, 2017). Adams' Equity Theory is accepted as the basis of distributive justice. In terms of being organizational, distributive justice means the distribution of organizational resources (awards and penalties) among the members of the organization, and the justice of this distribution results perceived by the employees. In this sense, distributive justice is seen as the starting point of justice and equality in organizations.

- Intergroup relations theory: One of the most important definitions of intergroup relations was explainedby Sherif (1962) who states that "Intergroup relations refer to relations between two or more groups andtheir respective members. Whenever individuals belonging to one group interact, collectively or individually, with another group or its members in terms of their group identifications we have an instance of intergroup behavior ." Intergroup relations theory indicates that uncertainty relationship between the minority group and others causes problems such as conflicts and unhappiness (Kossek and Zonia, 1993; Gonzalez and Denisi, 2009; Hofhuis et al. 2012; Ragins et al. 2012; Schachner et al. 2016; Cole et al. 2016). 
- Intergroup contact theory: Researchers began using the "social contact" after the World War II. Allport's writings on social contact have attracted much attention among the works done in that period (Pettigrew, 1998). Allport (1954) developed the social contact hypothesis in order to regulate the relations between the groups. The first assumptions in the social contact hypothes is that less information between two groups leads to prejudice.Allport's social contact hypothesis was used by Pettigrew (1998) as a concept of "intergroup contact" (Hofhuis et al. 2012; Schachner et al. 2016).

- The Resource-Based Theory: The question of why some organizations are more successful than othersexamines how organizations manage their relations with their external environment. The aim of the theory is to explain how organizations maintain their sustainable positions in the competitive environment. This theory focuses on productivitybased resources rather than other methods such as market power, secret agreement, or strategic behavior which organizations can make a difference compared to their competitors. Accordingly, organizations that have superior or distinctive resources and capabilities compared to their competitors obtain competitive advantage if they manage environmental opportunities correctly (Herdman and McMillan, 2010; Les Tien-Shang, 2011).

- Interactional model of cultural diversity: This model, developed by Cox (1993), explains the diversitiesat the individual, group and organizational level in relation with the organizational climate. This study emphasizes both individual and organizational outcomes of the diversity climate perceived by the employees (McKay et al. 2011; Boehm et al. 2014; Lauring and Selmer, 2011, 2012; Kaplan et al. 2011; Madera et al. 2013; Paolillo et al. 2017).

- Racial identity theory: Racial identity theory (Phinney, 1992) refers to the individual's self-conception as amember of a particular racial / ethnic group, to the level of attachment to the group, and the scope of participation in cultural activities. The theory states that minority groups are more dependent on ethnic identity and they strengthen the group's identity to protect themselves against counter-threatening threats (Mckay et al. 2007; Price et al. 2005; Hardeman et al. 2016; Guchait et al. 2016).

- Social Categorization theory: It is stated that shared values, loyalty level and compliance level increase atthe same rate depending on how highthe level of similarity between the individuals in the group is. On the other hand, it is emphasized that as the perceived diversity within the group increases, the categorization also increases in the context of social identity (gender, age, ethnic origin, race, religion, nationality, sexual orientation and socio-economic status) (Drach and Trogan, 2013).

- Signaling theory: Signaling theory provides a unique, practical, and empirically testable perspective onproblems of social selection under conditions of imperfect information. 
This theory suggests that employees should rely on organizational signs and signals while interpreting organization's goals and objectives. For example, for new applicants, the organization's corporate social performance gives various signs on organization's values, norms, and working conditions (Kaplan et al. 2011; Vargas et al. 2018; Hennekam and Ladge, 2017).

- Faultline Theory: Faultline theory explains how the characteristics of team members affect the behaviors ofthe team and ultimately its performance. The characteristics of team members can be surface diversity level (gender, age, nationality and education) or deep diversity level (values, personality). Strong faultlines arise in an organization when all of the demographic characteristics of the team members create different and non-overlapping categories. For example, if all the women in a team are over 50 years old and all men are under 30, it means that gender and age have formed a single and strong faultline and failure is inevitable (Chung et al. 2015).

\subsection{Units of Analysis in Diversity Climate Research}

The unit of analysis is primarily concerned with what is being studied or what the actor (s) of the study is (are). The analysis unit indicates "the thing" that is to be studied. When expressed in this way, the unit of analysis refers to an entity. Analytically, three units of analysis can be classified as: 1- a single individual as an actor, 2- groups of individuals or communities (gathering actors) and 3- universe or humanity (all-inclusive actor). Individuals and groups were selected as the units of analysis.

When analyzed specifically, it was determined that studies were conducted for students, employees and managers. As professional groups; scholars, service sector employees, sales representatives, finance sector employees, real estate company employees, hotel employees and managers, hospital employees (nurses and doctors), new product development team leaders and employees, immigrant students were determined as analysis units in the studies.

\subsection{Measuring the Diversity Climate}

The measurement tools of the articles mentioned in our study are as follows:

- Diversity climate scale was developed by Kossek and Zonia (1993) which contains 20 items for 4 factors. Diversity Climate scale factors measures value efforts to promote diversity, qualifications of racio-ethnic minorities, qualifications of women, department support for women, and racio-ethnic minorities.

- Diversity perception scale was developed by Mor Barak et al. (1998) which contains 16 items for 4 factors. It focuses on personal and organizational dimensions in a diversity climate. 
- The schools 'sexual diversity climate scale (SDC) was developed by Szalacha (2003) which contains 19 items. Scale questions measured on five-point Likert-type scales, included items about the curriculum, such as, "In the Health class, when studying sexuality and relationships, gay, lesbian, and bisexual people are included".

- Group openness to diversity scale was developed by Hobman et al. (2004) which contains 3 items. These items developed to measure each type of perceived group openness to diversity, perceived group openness to visible, informational and value diversity.

- Perceived diversity climate scale was developed by Gelfand et al. (2005) which contains 4 items. These items were formulated as follows: "The team makes it easy for people with different opinions or ideas to fit in and be accepted.", "Where I work, team members are developed in advance without regard to their opinions or ideas.", "The team leader demonstrates through their actions that they accept different opinions or ideas.", "I feel that my team leader does a good job of managing people with diverse opinions or ideas".

- Firm diversity climate scale was devoloped by Roberson (2006) which contains 21 items for organizational inclusiveness. Two representative items are "Diversity is a part of relevant education and training activities in the organization." and "Organizational members have equal access to leadership opportunities."

- Psychological diversity climate was measured using the four-item scale developed by Pugh et al. (2008). Example items were formulated as follows: "My company makes it easy for people from diverse backgrounds to fit in and be accepted." and "Where I work, employees are developed and advanced without regard to the gender or the racial, religious or cultural background of the individual".

- Age-diversity climate scale was measured with a seven-point likert scale in employee, applying 4 items that were closely related to the general diversity measure developed by Pugh et al. (2008). The four items were rephrased to address only specific age-diversity issues instead of general diversity as in the original scale. Item of scale include "Managers in our company demonstrate through their actions that they want to hire and retain an age-diverse workforce".

- Diversity climate perceptions scale was developed by McKay et al. (2008) which contains 4 items. Scale responses were scored on a five-point Likert scale. Items explore the equal and fair treatment, manager and leader support for diversity, recognition of diverse perspectives facet of diversity climate.

- Group-based openness to diversity scale was composed of 10 items for 4 factors. Scale factors measures: openness to linguistic diversity by Harzing and Feely (2008) and Hobman et al. (2004), openness to visible diversity, openness to value diversity, openness to informational diversity (seven-point scale adapted after Hobman et al. 2004). 
- Diversity climate scale was developed by Herdman and Capehart (2010) which contains 3 items that assess overall perceptions of a diversity climate within the organization. These items were "The hotel values differences in its employees." "I believe this hotel strives to have a very diverse workforce." and "The hotel makes sure the opinions and input of employees from different backgrounds are heard.".

- Diversity climate scale was composed of five items that were developed by Kaplan et al. (2011). Scale items include: "The leadership at my company is committed to diversity.". The scale was similar in structure and composition to other measures of diversity climate perceptions. Each item measured on a 5-point likert scale.

- Diversity Climate was developed by Hofhuis et al. (2012) that adapted from a Dutchlanguage scale originally generated by Kruithof (2001). Diversity climate scale contains four items. These items were formulated as follows: "In this organization there is room to work according to one's own culture", "In this organization we take into account different cultural traditions and habits of employees", "In this organization it is seen as an advantage to work with people of different cultural backgrounds" and "In this organization we appreciate different cultural backgrounds".

- Perceived community diversity climate was developed by Ragin et al. (2012) which contains 5 items. All items measured on a 5-point likert scale with the following five statements: "My community welcomes people of different races and ethnicities.", "Racial and ethnic diversity are not tolerated in my community.", "People of different races and ethnicities would want to move to my community.", "My community fosters a positive climate for people of different races and ethnicities." and "My community is a model for valuing racial and ethnic diversity.".

- Affirming climate for diversity scale developed a measure of diversity climate by Mason and Aramovich (2013) that included 15 items of four factors. These factors measures structural integration, informal integration, low cultural bias and intergroup cohesion.

- Perceived organizational value of diversity was developed by Avery et al. (2013) which contaains 4 items. The items were "Clearly, diversity is not important to this company." "Employees at this company are probably very similar to one another." "I suspect that this company discriminates against minorities." and "It is unlikely that this company employs many minorities.".

- Diversity climate scale was developed by Chung et al. (2015) which contains 8 items. The eight itemswere: "My coworkers help me feel like an important part of the team.", "My coworkers appreciate my background and perspective.", "My manager always treats me like a valued member of my team.", "My manager ensures that I always feel included at 
work.", "I receive many opportunities to work with diverse and multicultural teams.", "I have the same opportunities for career growth as my coworkers.", "This organization's actions demonstrate complete commitment to diversity with inclusion." and "Capable people succeed at all levels in this organization, regardless of the group that they belong to (gender, nationality, race, disability)".

- Equality and inclusion climate scale was measured as descriptive norms about intergroup contact (Allport, 1954) between immigrant and nonimmigrant students in the classroom. Scale was developed by Schachner et al. (2016) which contain 33 items for 5 factors. The scale comprised five factors: (a) perceived unequal treatment by teachers (six items; e.g. German children can take more liberties in front of the teacher than foreign children ), (b) perceived support for contact and cooperation by teachers (eight items; e.g. Our teachers want German and foreign children to help each other with course work ), (c) perceived unequal treatment by students (six items; e.g. In my classroom, foreign children are often teased by the other children ), (d) perceived support for contact by students (eight items; e.g. German and foreign children like to sit next to each other in my classroom ), and (e) perceived support for cooperation by students (five items; e.g. The German and the foreign children in my classroom stick together).

\subsection{Dimensions and Outcomes of Diversity Climate Research}

The first study on the diversity climate (Kossek and Zonia, 1993) examined diversities in terms of gender and ethnic identity. In this study, it is pointed out that there is a dominant heterogeneous culture "in the distribution of work force" in organizations in America. It is stated that caucasian have more career opportunities than others. It is also determined that women and minorities are subject to restrictions on accessing the organization resources and the perceived diversity climate is more negative. Similarly, McKay et al. (2007, 2008, 2009 , 2011) examined the individual and organizational results of the negative perception of diversity climate in their identity differences studies.

Another study reveals that the perception of the justice in team decisions in the organizations differ according to the marital status. The perception of justice of employees who are married and who have children is more negative (Price et al. 2005; Boehm et al. 2014). In similar studies, the perception of diversity climate was measured by variables such as age and duty duration. It has been determined that those who are younger and have less work duration than other employees are exposed to exclusion and mobbing behaviors (Chen et al. 2012; Drach and Trogan, 2013). The vast majority of the studies reviewed have examined the diversity climate in terms of ethnicity / race, being a woman, being different in terms of sexual orientation, working time and being different according to status, age. 
As a result of this study, it was determined that the perception of diversity climate have the following outcomes: organizational commitment (Mckay et al. 2007; Gonzalez and Denisi, 2009; Buttner et al. 2012), intention to quit and absenteeism (Kaplan et al. 2011; Buttner et al. 2010; Mckay et al. 2007; Gonzalez and Denisi, 2009; Ragins et al. 2012; Avery et al. 2013; Brimhall et al. 2014; Boehm et al. 2014; Buttner and Lowe, 2017), job satisfaction (McKay et al. 2008, 2011; Hofhuis et al. 2012; Price et al. 2009; Madera et al. 2013; Brimhall et al. 2014; Lauring and Selmer, 2011; Madera et al. 2016; Cole et al. 2016; Vargas et al. 2018; Guchait et al. 2016), firm effectiveness (Gonzalez and Denisi, 2009; Boehm et al. 2014), perception ofopenness to diversity (Kossek and Zonia, 1993; Pugh et al. 2008; Lauring and Selmer, 2012; Moon, 2018; Buttner and Lowe, 2017), trust in management and perception of justice (Guchait et al. 2016; Herdman and McMillan, 2010; Chung et al. 2015; Dwertmann et al. 2016), conflict (Hofhuis et al. 2012; Madera et al. 2013), stess level (Ragins et al. 2012; Vargas et al. 2018), leadership (Randal et al. 2016), communication (Goby et al. 2015; Hofhuis et al. 2016).

In this context, the main dimensions used in the studies examined and the outcomes are summarized as follows:

Table 7

Dimensions and Outcomes of Diversity Climate

Demographic Minority

\begin{tabular}{ll} 
Gender & Organizational commitment \\
Race & Job satisfaction \\
Etnicity & Job motivation \\
Religion & Stress level \\
Age & Burnout \\
Sexual Orientation & Perception of justice \\
Language $\quad$ Job Related & \\
Tenure & Organizational outcomes \\
Income & Turnover ratio \\
Status & Intent to quit \\
Workplace localization & Firm performance \\
HR practices & Conflict \\
Team strain & Leadership \\
& Support level \\
\hline
\end{tabular}

\subsection{Major Finding of Diversity Climate Research}

In the articles used for our study, the perceived heterogeneity in the workplace is one of the most important factors that affect the perceived diversity climate. Working environment 
and group behaviors are affected by employee heterogeneity. In this context, the remarkable results that have been found in the studies are as follows:

- Employees with different identity structures have higher loyalty to group identity. This situation comes in sight the most in ethnicity (race) diversity.

- The positive perceived diversity climate in the work environment has a positive effect on organizational performance.

- The attitudes and behaviors of the managers and team leaders affect the employees' perception of diversity climate.

- The human resources practices such as recruitment and promotion are effective on employees' perceptions of justice and discrimination.

- The heterogeneity of the organizations is effective on customer satisfaction.

- Positive perception of diversity climate decreases the turnover rate.

- Organizational commitment and job satisfaction are directly affected by the diversity climate.

- Diversity climate perceptions appear to be a key to employee retention.

- Turnover ratio and intention to quit are directly affected by the diversity climate.

- Diversity climate perceptions exhibited mediated effects on turnover intention through organizational commitment.

- The diversity climate supported in the work environment is effective on the quality of social relations. The main focus of these results indicates that a work environment that is free from discrimination, that is inclusive, integrative, affirming the differences, has a positive effect on individual and organizational outcomes.

\section{Conclusion}

Diversities related to humans can be seen in every aspect of our life. When considered in this context, diversities in the working life carry a great importance. The diversity climate, which we can describe as a metaphoric organizational atmosphere, reflects the employees' perception towards the diversities at the individual, group and organizational level. The diversity climate is an issue which organizational psychology and organizational behavior disciplines intensely work on. Our structured literature review on the diversity climate concept clearly shows that the diversity climate has importance in predicting attitudes, behaviors and beliefs. If we briefly summarize the results of our evaluation and synthesis; 
- While the majority of the reviewed studies reveal the justice and discrimination aspects of the diversity climate with an ethical approach, we defend the idea that the diversities should be evaluated in terms of culture and from an insider perspective. Similarly, Tatl1 and Özbilgin (2012) emphasize the need to be sensitive to the characteristics of the place, time, and place of study when performing intersectional analysis of diversities.

- Diversity climate studies were mostly based on surface differences. Gender, race, ethnicity, and age are the focal points of the first studies.In the following periods, issues such as experience, employee status and income were studied. It is determined from the studies reviewed that the subjects of deep diversities such as personality, attitudes and beliefs are largely neglected. In addition to this, while there was a very limited number of studies in the past, it was determined that the number of studies conducted on the diversities in the secondary (deep) category such as sexual orientation, which can be easily hidden, increased in the last five years.

- When the results of the perceived difference climate are evaluated, job satisfaction and organizational commitment are the most common outcomes among the individual career outcomes. The positive diversity climate always has positive results. Performance, conflict environment, intention to quit, leadership and management support as the outcomes of organizational effectiveness are important results of the perceived diversity climate. It has been found that organizational culture has been a neglected issue. We know that if an organization's culture has a structure that appreciates and accepts the diversities, the perceived diversity climate takes a positive form.

However, we would like to state that all these evaluations are limited to the articles in the relevant database. We believe that our study based on evaluation and synthesis of diversity climate will be a reference for further advanced studies.

Peer-review: Externally peer-reviewed.

Conflict of Interest: The authors have no conflict of interest to declare.

Grant Support: The authors declared that this study has received no financial support.

\section{References}

Adams, J. S. (1963). Toward an understanding of inequity. Journal of Abnormal Social Psychology, 67, $422-436$.

Aksan, N., Kısaç, B., Aydın, M., \& Demirbuken, S. (2009). Symbolic interaction theory. Procedia Social and Behavioral Sciences, 1(2), 902-904.

Allport, G. W. (1954). The nature of prejudice. Reading, MA: Addison-Wesley. 537.

Avery, D. R., Volpone, S. D., Stewart, R. W., Luksyte, A., Hernandez, M., Mckay, P. F., \& He, M. R. (2013). Examining the draw of diversity: How diversity climate perceptions affect job-pursuit intentions. Human Resource Management, 52(4), 123-148. 
Boehm, S. A., Kunze, F., \& Bruch, H. (2014). Spotlight on age-diversity climate: the impact of age-inclusive hr practices on firm-level outcomes. Personnel Psychology, 21(5), 120-142.

Brimhall, K. C., Lizano, E. L., \& Mor-Barak, M. E. (2014). The mediating role of inclusion: A longitudinal study of the effects of leader-member exchange and diversity climate on job satisfaction and intention to leave among child welfare workers children and youth. Services Review, 18(3), 40-58.

Buttner, E. H., \& Lowe, K. B. (2017). Addressing internal stakeholders' concerns: the interactive effect of perceived pay equity and diversity climate on turnover intentions. Journal Of Business Ethics, 45(5), $143-160$.

Buttner, E. H., Lowe, K. B., \& Billings H. L. (2010). Diversity climate impact on employee of color outcomes: Does justice matter? Career Development International, 15(3), 123-149.

Buttner, E. H., Lowe, K. B., \& Billings, H. L. (2012). An empirical test of diversity climate dimensionality and relative effects on employee of color outcomes. Journal of Business Ethics, 12(2), 110-134.

Chen, X. P., Liu, D., \& Portnoy, R. (2012). A multilevel investigation of motivational cultural intelligence, organizational diversity climate, and cultural sales: Evidence from US real estate firms. Journal of Applied Psychology, 23(4), 97-123.

Chung, Y., Liao, H., Jackson, S. E., Subramony, M., Colakoglu, S., \& Jiang, Y. (2015). Cracking but not breaking: joint effects of faultline strength and diversity climate on loyal behavior. Academy Of Management Journal, 58(3), 12-36.

Cole, B., Jones, R. J., \& Russell, L. M. (2016). Racial dissimilarity and diversity climate effect organizational identification. Equality, Diversity and Inclusion, 35(4), 43-65.

Cox, T. (1993). Culturaal diversity in organizations: Theory, research and practise. San Francisco: BerrettKoehler.

Drach-Zahavy, A., \& Trogan, R.(2013). Opposites attract or attack? the moderating role of diversity climate in the team diversity-interpersonal aggression relationship. Journal of Occupational Health Psychology, $18(4), 21-39$.

Dwertmann, D. J. G., Nishii, L. H., \& Van Knippenberg, D. (2016). disentangling the fairness \& discrimination and synergy perspectives on diversity climate: Moving the field forward. Journal of Management, 42(4), 234-259.

Employee Retention: Are Diversity Climate Perceptions The Key? Personnel Psychology. 60(3),45-62.

Gelfand, M. J., Nishii, L. H., Raver, J., \& Schneider, B. (2005). Discrimination in Organizations: An Organizational Level Systems Perspective. In R. Dipboye \& A. Colella (Eds.), Discrimination At Work: The Psychological and Organizational Bases (89-116). Mahwah, NJ: Erlbaum.

Goby, V. P., Nickerson, C., \& David, E. (2015). Interpersonal communication and diversity climate: promoting workforce localization in the USA. International Journal of Organizational Analysis, 23(2), 34-51.

Gonzalez, J. A., Denisi, A. S. (2009). Cross-level effects of demography and diversity climate on organizational attachment and firm effectiveness. Journal of Organizational Behavior, 30(4), 11-37.

Guchait, P., Madera, J., \& Dawson, M. (2016). Learning in the service environment: the influence of diversity climate. Journal of Service Theory and Practice, 26(4), 32-56.

Hardeman, R. R., Medina, E. M., \& Kozhimannil, K. B. (2016). Structural racism and supporting black lives — the role of health professionals. The New England Journal of Medicine, 375(15), 2113-2115. 
Hardeman, R. R., Przedworski, J. M., Burke, S., Burgess, D. J., Perry, S., Phelan, S., Dovidio, J. F., \& Van Ryn, M. (2016). Association between perceived medical school diversity climate and change in depressive symptoms among medical students: A report from the medical student change study. Journal of The National Medical Association, 23(5),108-129.

Harzing, A.W.K., \& Feely, A.J. (2008). The language barrier and its implications for HQ subsidiary relationships. Cross Cultural Management: An International Journal, 15(1), 49-60.

Hennekam, Sophie A. M., \& Ladge, J. J. (2017). When lesbians become mothers: Identity validation and the role of diversity climate. Journal of Vocational Behavior, 19(3),103-135.

Herdman, A. O., \& Mcmillan-Capehart, A. (2010). Establishing a diversity program is not enough: Exploring the determinants oo diversity climate. Journal of Business and Psychology, 25(4), 10-37.

Hobman, E. V., Bordia, P., \& Gallois, C. (2004). Perceived Dissimilarity and Work Group Involvement: The Moderating Effects of Group Openness to Diversity. Group \& Organization Management, 29(5), $560-587$.

Hofhuis, J., Van Der Rijt, Pernill G. A., \& Vlug, M. (2016). Diversity climate enhances work outcomes through trust and openness in workgroup communication. SpringerPlus, 11(5), 3-14.

Hofhuis, J., Van Der Zee, K. I., \& Otten, S. (2012). Social identity patterns in culturally diverse organizations: the role of diversity climate. Journal of Applied Social Psychology, 42(5), 54-73.

Kaplan, D. M., Wiley, J. W., \& Maertz, C. P. (2011). The role of calculative attachment in the relationship between diversity climate and retention. Human Resource Management, 50(3),78-90.

Kossek, E., \& Zonia, S. (1993). Assessing diversity climate - a field-study of reactions to employer efforts to promote diversity. Journal of Organizational Behavior, 14(2), 123-146.

Lauring, J., \& Selmer, J. (2012). International language management and diversity climate in multicultural organizations. International Business Review, 21(3), 3-29.

Lauring, J., \& Selmer, J. (2011). Multicultural organizations: does a positive diversity climate promote performance? European Management Review, 12(8), 25-38.

Lee, Les Tien-S. (2011). The effects of environmental dynamism and team strain on product innovation: the moderating role of perceived diversity climate. African Journal Of Business Management, 22(4), 456-487.

Madera, J. M., Dawson, M., \& Guchait, P. (2016). Psychological diversity climate: Justice, racioethnic minority status and job satisfaction. International Journal Of Contemporary Hospitality Management, 28(4), 321-345.

Madera, J. M., Dawson, M., \& Neal, J. A. (2013). Hotel managers' perceived diversity climate and job satisfaction: the mediating effects of role ambiguity and conflict. International Journal of Hospitality Management, 35(6),12-34.

Mason, D. C., \& Aramovich, N. (2013). the psychological benefits of creating an affirming climate for workplace diversity. Group \& Organization Management, 38(6), 659-689.

Mckay, P. F., Avery, D. R., Liao, H., \& Morris, M. A. (2011). does diversity climate lead to customer satisfaction? It depends on the service climate and business unit demography. Organization Science, $22(4), 45-61$.

Mckay, P. F., Avery, D. R., \& Morris, M. A. (2008). Mean racial-ethnic differences in employee sales performance: the moderating role of diversity climate. Personnel Psychology, 61(4), 76-90. 
Mckay, P. F., Avery, D. R., \& Morris, M. A. (2009). A tale of two climates: Diversity climate from subordinates' and managers' perspectives and their role in store unit sales performance. Personnel Psychology, 62(5), 65-89.

Mckay, P. F., Avery, D. R., Tonidandel, S., Morris, M. A., Hernandez, M., \& Hebl, M. R. (2007). Racial Differences in

Moon, Kuk-K. (2018). How does a diversity climate shape the relationship between demographic diversity and organizational social capital in the US federal government? Public Management Review, 20(4), 4867.

Mor Barak, M. Cherin, D., \& Berkman, S. (1998). Organizational and personal dimensions in diversity climate. The Journal of Applied Behavioral Science, 34(1), 82-104.

Paolillo, A., Pasini, M., Silva, S. A., \& Magnano, P.(2017). Psychometric properties of the italian adaptation of the mor barak et al. diversity climate scale. Quality \& Quantity, 51(2), 345-368.

Pettigrew, T. (1998). Intergroup contact theory. Annual Review Psychology, 49, 65-85.

Phinney, JS. (1992). The multigroup ethnic identity measure: A new scale for use with diverse groups. Journal Of Adolescent Research, 32, 145-172.

Price, E. G., Powe, N. R., Kern, D. E., Golden, S. H., Wand, G. S., \& Cooper, L. A. (2009). Improving the diversity climate in academic medicine: Faculty perceptions as a catalyst for institutional change. Journal of Academic Medicine, 84(4), 35-56.

Price, E., Gozu, A., Kern, D., Powe, N., Wand, G., Golden, S., \& Cooper, L.(2005). The role of cultural diversity climate in recruitment, promotion, and retention of facultyi academic medicine. Journal Of General Internal Medicine. 20(3), 121-145.

Pugh, S. D., Dietz, J., Brief, A. P., \& Wiley, J. W. (2008). Looking inside and out: the impact of employee and community demographic composition on organizational diversity climate. Journal of Applied Psychology, 93(4), 25-42.

Ragins, B. R., Gonzalez, J. A., Ehrhardt, K., \& Singh, R. (2012). Crossing the threshold: the spillover of community racial diversity and diversity climate to the workplace. Personnel Psychology, 65(4), 98-124.

Randel, A. E., Dean, M. A., Ehrhart, K. H., Chung, Be., \& Shore, L.(2016). Leader inclusiveness, psychological diversity climate, and helping behaviors. Journal of Managerial Psychology, 31(4), 245-267.

Roberson, Q., Ryan, A. M., \& Ragins, B. R. (2017). The evolution and future of diversity at work. Journal of Applied Psychology, 102(3), 483-499.

Schachner, M. K., Noack, P., Van De Vijver, Fons J. R., \& Eckstein, K. (2016). Cultural diversity climate and psychological adjustment at school-equality and inclusion versus cultural pluralism. Journal of Child Development, 87(4), 22-45.

Sherif, M. (1962). Intergroup Relations and Leadership: Approaches and Research in Industrial, Ethnic, Cultural and Political Areas. Oxford, England: John Wiley.

Sliter, M., Boyd, E., Sinclair, R., Cheung, J., \& Mcfadden, A.(2014). Inching toward inclusiveness: Diversity climate, interpersonal conflict and well-being in women nurses. Sex Roles, 71(3),68-94.

Sukoco, B. M., \& Lee, Les Tien-S. (2017). The effects of psychological capital and team strain on the effectiveness of NPD teams: the moderating role of perceived diversity climate. International Journal of Innovation Management, 21(5), 45-67.

Tajfel, H., \& Turner, J. C. (1979). An Integrative Theory of Intergroup Conflict. In W. G. Austin \& S. Worchel (Eds.), The Social Psychology of Intergroup Relations: 33-47. Monterey, CA: Brooks-Cole. 
Tatlı A., \& Özbilgin M. (2012). An emic approach to intersectional study of diversity at work: A bourdieuan framing. International Journal Of Management Review, 14(1), 180-200.

Vargas, E., Westmoreland, A. S., Robotham, K., \& Lee, F.(2018). Counting heads vs making heads count: Impact of numeric diversity and diversity climate on psychological outcomes for faculty of color. Equality Diversity and Inclusion, 37(1), 182-210. 


\section{Appendix}

Table 6

The Evolution of Diversity Climate Theory and Research

\begin{tabular}{|c|c|c|c|c|c|c|c|c|}
\hline NO: & $\begin{array}{c}\text { Source } \\
\text { Title }\end{array}$ & Dimension & Theory & $\begin{array}{c}\text { Unit of } \\
\text { Analysis }\end{array}$ & Country & $\begin{array}{c}\text { N of } \\
\text { sample }\end{array}$ & Methodogy & Outcomes \\
\hline 1 & $\begin{array}{c}\text { Kossek } \\
\text { and Zonia } \\
(1993)\end{array}$ & Gender, race & $\begin{array}{l}\text { Intergroup } \\
\text { relations } \\
\text { theory }\end{array}$ & Academics & USA & 775 & $\begin{array}{l}\text { Survey, } \\
\text { statistical } \\
\text { analysis }\end{array}$ & $\begin{array}{c}\text { Favorable diversity } \\
\text { activities }\end{array}$ \\
\hline 2 & $\begin{array}{l}\text { Price et al. } \\
\text { (2005) }\end{array}$ & $\begin{array}{l}\text { Race,gender, } \\
\text { religion, } \\
\text { sexual } \\
\text { orientation }\end{array}$ & $\begin{array}{c}\text { Social } \\
\text { identity } \\
\text { theory, } \\
\text { Racial } \\
\text { identity } \\
\text { theory }\end{array}$ & Physicians & USA & 5 & $\begin{array}{l}\text { Qualitative } \\
\text { study }\end{array}$ & $\begin{array}{l}\text { Recruitment, } \\
\text { promotion }\end{array}$ \\
\hline 3 & $\begin{array}{l}\text { Mckay et } \\
\text { al. (2007) }\end{array}$ & $\begin{array}{c}\text { Race, diversity } \\
\text { perceptions }\end{array}$ & $\begin{array}{c}\text { Social } \\
\text { identity } \\
\text { theory, } \\
\text { Racial } \\
\text { identity } \\
\text { theory }\end{array}$ & $\begin{array}{l}\text { Managerial } \\
\text { employees }\end{array}$ & USA & 6823 & $\begin{array}{l}\text { Survey, } \\
\text { statistical } \\
\text { analysis }\end{array}$ & $\begin{array}{l}\text { Organizational } \\
\text { commitment, } \\
\text { turnover intentions }\end{array}$ \\
\hline 4 & $\begin{array}{l}\text { McKay et } \\
\text { al. (2008) }\end{array}$ & $\begin{array}{l}\text { Diversity } \\
\text { climate } \\
\text { perception }\end{array}$ & $\begin{array}{l}\text { Intergroup } \\
\text { relations } \\
\text { theory }\end{array}$ & $\begin{array}{c}\text { Subordinates } \\
\text { and managers }\end{array}$ & USA & 654 & $\begin{array}{l}\text { Survey, } \\
\text { statistical } \\
\text { analysis }\end{array}$ & $\begin{array}{c}\text { Sales performance, } \\
\text { organizational } \\
\text { identification, job } \\
\text { satisfaction }\end{array}$ \\
\hline 5 & $\begin{array}{l}\text { Pugh et al. } \\
\text { (2008) }\end{array}$ & $\begin{array}{l}\text { Race, Gender, } \\
\text { Income }\end{array}$ & $\begin{array}{c}\text { Intergorup } \\
\text { Conflict } \\
\text { theory } \\
\end{array}$ & $\begin{array}{l}\text { Financial } \\
\text { sector } \\
\text { employees } \\
\end{array}$ & USA & 2369 & $\begin{array}{l}\text { Survey, } \\
\text { statistical } \\
\text { analysis }\end{array}$ & $\begin{array}{l}\text { Workforce racial } \\
\text { composition }\end{array}$ \\
\hline 6 & $\begin{array}{l}\text { McKay et } \\
\text { al. (2009) }\end{array}$ & Race, ethnicity & $\begin{array}{c}\text { Social } \\
\text { identity } \\
\text { theory }\end{array}$ & $\begin{array}{c}\text { Sales } \\
\text { employees }\end{array}$ & USA & 613 & $\begin{array}{l}\text { Survey, } \\
\text { statistical } \\
\text { analysis }\end{array}$ & Sales performance \\
\hline 7 & $\begin{array}{l}\text { Gonzalez } \\
\text { and Denisi } \\
\text { (2009) }\end{array}$ & Gender, race & $\begin{array}{l}\text { Intergroup } \\
\text { relations } \\
\text { theory }\end{array}$ & $\begin{array}{l}\text { Service sector } \\
\text { employees }\end{array}$ & USA & 271 & $\begin{array}{l}\text { Survey, } \\
\text { statistical } \\
\text { analysis }\end{array}$ & $\begin{array}{l}\text { Organizational } \\
\text { commitment and } \\
\text { identification } \\
\text {,intention } \\
\text { to quit,firm } \\
\text { effectiveness }\end{array}$ \\
\hline 8 & $\begin{array}{l}\text { Price et al. } \\
\text { (2009) }\end{array}$ & $\begin{array}{l}\text { race/ethnicity, } \\
\text { gender, } \\
\text { academic rank, } \\
\text { birth status }\end{array}$ & $\begin{array}{l}\text { Social } \\
\text { identity } \\
\text { theory }\end{array}$ & Physicians & USA & 352 & $\begin{array}{l}\text { a cross- } \\
\text { sectional } \\
\text { survey }\end{array}$ & $\begin{array}{l}\text { Job satisfaction, } \\
\text { recruitment, } \\
\text { promotion }\end{array}$ \\
\hline 9 & $\begin{array}{l}\text { Herdman } \\
\text { and } \\
\text { McMillan } \\
(2010)\end{array}$ & $\begin{array}{l}\text { Sex, race/ } \\
\text { ethnicity }\end{array}$ & $\begin{array}{c}\text { The } \\
\text { resource- } \\
\text { based } \\
\text { theory }\end{array}$ & $\begin{array}{c}\text { Hotel } \\
\text { employees }\end{array}$ & USA & 3578 & $\begin{array}{l}\text { Survey, } \\
\text { statistical } \\
\text { analysis }\end{array}$ & $\begin{array}{l}\text { Managerial values, } \\
\text { Diversity initiatives }\end{array}$ \\
\hline 10 & $\begin{array}{l}\text { Buttner et } \\
\text { al. }(2010)\end{array}$ & $\begin{array}{l}\text { Equal } \\
\text { opportunities, } \\
\text { Ethnic groups }\end{array}$ & $\begin{array}{l}\text { Social } \\
\text { exchange } \\
\text { theory, } \\
\text { Social } \\
\text { identity } \\
\text { theory }\end{array}$ & Professionals & USA & 182 & $\begin{array}{l}\text { survey, } \\
\text { statistical } \\
\text { analysis }\end{array}$ & $\begin{array}{l}\text { Interactional and } \\
\text { procedural justice, } \\
\text { organizational } \\
\text { commitment and } \\
\text { turnover intention, } \\
\text { social justice }\end{array}$ \\
\hline
\end{tabular}




\begin{tabular}{|c|c|c|c|c|c|c|c|c|}
\hline NO: & $\begin{array}{c}\text { Source } \\
\text { Title }\end{array}$ & Dimension & Theory & $\begin{array}{c}\text { Unit of } \\
\text { Analysis }\end{array}$ & Country & $\begin{array}{c}\mathrm{N} \text { of } \\
\text { sample }\end{array}$ & Methodogy & Outcomes \\
\hline 11 & $\begin{array}{c}\text { Mckay et al. } \\
\text { (2011) }\end{array}$ & $\begin{array}{c}\text { Minority, } \\
\text { demography }\end{array}$ & $\begin{array}{c}\text { Interactional } \\
\text { model of } \\
\text { Cultural } \\
\text { diversity }\end{array}$ & $\begin{array}{c}\text { Retail } \\
\text { organization }\end{array}$ & USA & 59592 & $\begin{array}{l}\text { Survey, } \\
\text { statistical } \\
\text { analysis }\end{array}$ & $\begin{array}{c}\text { Customer } \\
\text { satisfaction }\end{array}$ \\
\hline 12 & $\begin{array}{l}\text { Kaplan et al. } \\
\text { (2011) }\end{array}$ & Race, gender & $\begin{array}{l}\text { Signaling } \\
\text { theory }\end{array}$ & Employees & USA & 4184 & $\begin{array}{c}\text { Survey } \\
\text { statistical } \\
\text { analysis }\end{array}$ & $\begin{array}{l}\text { Turnover } \\
\text { intention }\end{array}$ \\
\hline 13 & $\begin{array}{c}\text { Lauring } \\
\text { and Selmer } \\
\text { (2011) }\end{array}$ & $\begin{array}{l}\text { Demographic } \\
\text { heterogeneity }\end{array}$ & $\begin{array}{c}\text { Interactional } \\
\text { model of } \\
\text { cultural } \\
\text { diversity }\end{array}$ & Academics & Netherlands & 489 & $\begin{array}{c}\text { Survey } \\
\text { statistical } \\
\text { analysis }\end{array}$ & $\begin{array}{c}\text { Organizational } \\
\text { performance, job } \\
\text { satisfaction }\end{array}$ \\
\hline 14 & $\begin{array}{l}\text { Les Tien- } \\
\text { Shang } \\
(2011)\end{array}$ & $\begin{array}{l}\text { Team strain, } \\
\text { team anxiety, } \\
\text { team crisis }\end{array}$ & $\begin{array}{c}\text { Innovation } \\
\text { Theory }\end{array}$ & $\begin{array}{c}\text { New product } \\
\text { development } \\
\text { team }\end{array}$ & Taiwan & 423 & $\begin{array}{c}\text { Survey } \\
\text { statistical } \\
\text { analysis }\end{array}$ & $\begin{array}{c}\text { Product } \\
\text { innovation }\end{array}$ \\
\hline 15 & $\begin{array}{l}\text { Hofhuis et } \\
\text { al. (2012) }\end{array}$ & $\begin{array}{c}\text { Cultural } \\
\text { background }\end{array}$ & $\begin{array}{l}\text { Intergroup } \\
\text { contact } \\
\text { theory, Social } \\
\text { identity } \\
\text { theory }\end{array}$ & $\begin{array}{c}\text { Employees } \\
\text { of the public } \\
\text { service }\end{array}$ & Netherland & 1111 & $\begin{array}{c}\text { Survey } \\
\text { statistical } \\
\text { analysis }\end{array}$ & $\begin{array}{c}\text { job satisfaction, } \\
\text { job recognition, } \\
\text { conflict }\end{array}$ \\
\hline 16 & $\begin{array}{l}\text { Lauring } \\
\text { and Selmer } \\
\text { (2012) }\end{array}$ & $\begin{array}{l}\text { Demographic } \\
\text { heterogeneity }\end{array}$ & $\begin{array}{c}\text { Interactional } \\
\text { model of } \\
\text { Cultural } \\
\text { diversity }\end{array}$ & Academics & Netherlands & 489 & $\begin{array}{l}\text { Survey, } \\
\text { statistical } \\
\text { analysis }\end{array}$ & $\begin{array}{l}\text { Language } \\
\text { management, } \\
\text { Openness to } \\
\text { diversity }\end{array}$ \\
\hline 17 & $\begin{array}{l}\text { Ragins et al. } \\
\text { (2012) }\end{array}$ & $\begin{array}{l}\text { Community } \\
\text { diversity, } \\
\text { people of } \\
\text { color, race }\end{array}$ & $\begin{array}{l}\text { Intergroup } \\
\text { relations } \\
\text { theory }\end{array}$ & Professionals & USA & 2045 & $\begin{array}{l}\text { Survey, } \\
\text { statistical } \\
\text { analysis }\end{array}$ & $\begin{array}{c}\text { Moving } \\
\text { Intentions, } \\
\text { turnover } \\
\text { intentions, job } \\
\text { search behaviors, } \\
\text { stress at work }\end{array}$ \\
\hline 18 & $\begin{array}{l}\text { Buttner et } \\
\text { al. (2012) }\end{array}$ & $\begin{array}{l}\text { Employee of } \\
\text { color }\end{array}$ & $\begin{array}{l}\text { Intergroup } \\
\text { contract } \\
\text { theory }\end{array}$ & Professionals & USA & 154 & $\begin{array}{c}\text { Survey } \\
\text { statistical } \\
\text { analysis }\end{array}$ & $\begin{array}{c}\text { Organizational } \\
\text { commitment, } \\
\text { turnover } \\
\text { intentions }\end{array}$ \\
\hline 19 & $\begin{array}{c}\text { Chen et al. } \\
\text { (2012) }\end{array}$ & $\begin{array}{c}\text { Gender, } \\
\text { ethnicity, } \\
\text { age, number } \\
\text { of language, } \\
\text { tenure }\end{array}$ & $\begin{array}{c}\text { Trait } \\
\text { activation } \\
\text { theory, } \\
\text { Systems } \\
\text { theory }\end{array}$ & $\begin{array}{c}\text { Employees of } \\
\text { Real Estate } \\
\text { Firms }\end{array}$ & USA & 401 & $\begin{array}{l}\text { Survey, } \\
\text { statistical } \\
\text { analysis }\end{array}$ & $\begin{array}{c}\text { Cultural sales, } \\
\text { motivational } \\
\text { cultural } \\
\text { intelligence, }\end{array}$ \\
\hline 20 & $\begin{array}{l}\text { Drach and } \\
\text { Trogan } \\
(2013)\end{array}$ & $\begin{array}{c}\text { Etnicity, race, } \\
\text { age, sex, } \\
\text { tenure }\end{array}$ & $\begin{array}{c}\text { Social } \\
\text { categorization } \\
\text { theory }\end{array}$ & Nursing staff & Israel & 130 & $\begin{array}{c}\text { Survey } \\
\text { statistical } \\
\text { analysis }\end{array}$ & $\begin{array}{c}\text { Interpersonal } \\
\text { aggression, } \\
\text { bullying }\end{array}$ \\
\hline 21 & $\begin{array}{l}\text { Madera et } \\
\text { al. (2013) }\end{array}$ & $\begin{array}{l}\text { Diversity } \\
\text { climate }\end{array}$ & $\begin{array}{c}\text { Cultural } \\
\text { diversity } \\
\text { model }\end{array}$ & $\begin{array}{c}\text { Hotel } \\
\text { managers }\end{array}$ & USA & 130 & $\begin{array}{c}\text { Statistical } \\
\text { analysis }\end{array}$ & $\begin{array}{l}\text { Conflict, job } \\
\text { satisfaction }\end{array}$ \\
\hline NO: & Source Title & Dimension & Theory & $\begin{array}{c}\text { Unit of } \\
\text { Analysis }\end{array}$ & Country & $\begin{array}{c}\mathrm{N} \text { of } \\
\text { sample }\end{array}$ & Methodogy & Outcomes \\
\hline 22 & $\begin{array}{c}\text { Avery et al. } \\
\text { (2013) }\end{array}$ & $\begin{array}{l}\text { Sex, } \\
\text { racioethnicity }\end{array}$ & $\begin{array}{c}\text { Social } \\
\text { identity } \\
\text { theory }\end{array}$ & Students & USA & 449 & $\begin{array}{c}\text { survey, } \\
\text { statistical } \\
\text { anaylsis }\end{array}$ & $\begin{array}{c}\text { Job-pursuit } \\
\text { intentions }\end{array}$ \\
\hline
\end{tabular}




\begin{tabular}{|c|c|c|c|c|c|c|c|c|}
\hline NO: & $\begin{array}{c}\text { Source } \\
\text { Title }\end{array}$ & Dimension & Theory & $\begin{array}{c}\text { Unit of } \\
\text { Analysis }\end{array}$ & Country & $\begin{array}{c}\begin{array}{c}\text { N of } \\
\text { sample }\end{array} \\
\end{array}$ & Methodogy & Outcomes \\
\hline 23 & $\begin{array}{l}\text { Brimhall et } \\
\text { al. (2014) }\end{array}$ & $\begin{array}{c}\text { Child } \\
\text { welfare } \\
\text { workers } \\
\text { inclusion }\end{array}$ & $\begin{array}{l}\text { Symbolic } \\
\text { interaction } \\
\text { theory }\end{array}$ & Employees & USA & 363 & $\begin{array}{c}\text { survey } \\
\text { statistical } \\
\text { analysis }\end{array}$ & $\begin{array}{l}\text { Leader-member } \\
\text { exchange, Job } \\
\text { satisfaction, } \\
\text { Intention to leave }\end{array}$ \\
\hline 24 & $\begin{array}{l}\text { Sliter et al. } \\
\text { (2014) }\end{array}$ & Gender & $\begin{array}{l}\text { Interpersonal } \\
\text { conflict } \\
\text { theroy }\end{array}$ & $\begin{array}{l}\text { White } \\
\text { women } \\
\text { nurses }\end{array}$ & USA & 172 & $\begin{array}{c}\text { survey } \\
\text { statistical } \\
\text { analysis }\end{array}$ & $\begin{array}{l}\text { Engagement, } \\
\text { bunout, }\end{array}$ \\
\hline 25 & $\begin{array}{c}\text { Goby et al. } \\
\text { (2015) }\end{array}$ & $\begin{array}{c}\text { Diversity } \\
\text { climate, } \\
\text { Workforce } \\
\text { localization }\end{array}$ & Equity theory & $\begin{array}{c}\text { Emirati } \\
\text { employees }\end{array}$ & $\begin{array}{c}\text { Dubai- } \\
\text { United Arab } \\
\text { Emirates }\end{array}$ & 458 & $\begin{array}{l}\text { survey } \\
\text { statistical } \\
\text { analysis }\end{array}$ & Communication \\
\hline 26 & $\begin{array}{l}\text { Chung et al. } \\
\text { (2015) }\end{array}$ & $\begin{array}{l}\text { Demographic } \\
\text { diversity }\end{array}$ & $\begin{array}{l}\text { Faultline } \\
\text { Theory }\end{array}$ & $\begin{array}{l}\text { Managerial } \\
\text { employees }\end{array}$ & 22 counties & 1652 & $\begin{array}{c}\text { survey } \\
\text { statistical } \\
\text { analysis }\end{array}$ & Loyalty,support \\
\hline 27 & $\begin{array}{l}\text { Randel et al. } \\
\text { (2016) }\end{array}$ & $\begin{array}{l}\text { Diversity } \\
\text { climate }\end{array}$ & $\begin{array}{l}\text { Social } \\
\text { identity } \\
\text { theory }\end{array}$ & Employees & USA & 534 & $\begin{array}{c}\text { survey } \\
\text { statistical } \\
\text { analysis }\end{array}$ & $\begin{array}{l}\text { 1Ladership, } \\
\text { helping behaviors }\end{array}$ \\
\hline 28 & $\begin{array}{l}\text { Hofhuis et } \\
\text { al.(2016) }\end{array}$ & $\begin{array}{l}\text { Workplace } \\
\text { diversity }\end{array}$ & $\begin{array}{l}\text { Social } \\
\text { identity } \\
\text { theory }\end{array}$ & employees & Netherlands & 337 & $\begin{array}{l}\text { survey, } \\
\text { statistical } \\
\text { analysis }\end{array}$ & $\begin{array}{c}\text { Workgroup } \\
\text { communication, } \\
\text { Trust, Openness, } \\
\text { Knowledge } \\
\text { sharing }\end{array}$ \\
\hline 29 & $\begin{array}{l}\text { Hardeman } \\
\text { et al. (2016) }\end{array}$ & $\begin{array}{c}\text { Negative } \\
\text { racial climate }\end{array}$ & $\begin{array}{l}\text { Racial } \\
\text { identity } \\
\text { theory }\end{array}$ & $\begin{array}{c}\text { Medical } \\
\text { student }\end{array}$ & USA & 3756 & $\begin{array}{c}\text { survey } \\
\text { statistical } \\
\text { analysis }\end{array}$ & $\begin{array}{c}\text { Depressive } \\
\text { symptoms, well } \\
\text { being }\end{array}$ \\
\hline 30 & $\begin{array}{l}\text { Cole et al. } \\
\text { (2016) }\end{array}$ & $\begin{array}{l}\text { Race/ethnicity } \\
\text { gender, } \\
\text { employment } \\
\text { status }\end{array}$ & $\begin{array}{l}\text { Social } \\
\text { identity } \\
\text { theory, } \\
\text { Intergroup } \\
\text { relation } \\
\text { theory } \\
\end{array}$ & Employees & USA & 227 & $\begin{array}{c}\text { survey } \\
\text { statistical } \\
\text { analysis }\end{array}$ & $\begin{array}{l}\text { Organizational } \\
\text { identification, job } \\
\text { satisfaction }\end{array}$ \\
\hline 31 & $\begin{array}{l}\text { Schachner } \\
\text { et al. (2016) }\end{array}$ & $\begin{array}{c}\text { Race, } \\
\text { immigrant }\end{array}$ & $\begin{array}{l}\text { Intergroup } \\
\text { contact theory }\end{array}$ & $\begin{array}{l}\text { Immigrant } \\
\text { student }\end{array}$ & Germany & 386 & $\begin{array}{l}\text { Survey, } \\
\text { statistical } \\
\text { analysis }\end{array}$ & $\begin{array}{c}\text { Psychological } \\
\text { school } \\
\text { adjustment, } \\
\text { acculturation } \\
\text { orientations } \\
\end{array}$ \\
\hline 32 & $\begin{array}{l}\text { Dwertmann } \\
\text { et al. (2016) }\end{array}$ & $\begin{array}{l}\text { Race and } \\
\text { Ethnicity }\end{array}$ & $\begin{array}{c}\text { Social } \\
\text { identity } \\
\text { theory } \\
\end{array}$ & Meta analysis & $\begin{array}{l}\text { EBSCO } \\
\text { data base }\end{array}$ & $\begin{array}{c}143 \\
\text { articles }\end{array}$ & $\begin{array}{l}\text { theory- } \\
\text { driven } \\
\text { review }\end{array}$ & $\begin{array}{c}\text { Fairness and } \\
\text { discrimination, } \\
\text { synergy, inclusion }\end{array}$ \\
\hline 33 & $\begin{array}{l}\text { Guchait et } \\
\text { al. (2016) }\end{array}$ & $\begin{array}{c}\text { Racioethnic } \\
\text { minority } \\
\text { status }\end{array}$ & $\begin{array}{l}\text { Racial identity } \\
\text { theory }\end{array}$ & $\begin{array}{l}\text { Frontline } \\
\text { managers }\end{array}$ & USA & 164 & $\begin{array}{c}\text { survey } \\
\text { statistical } \\
\text { analysis }\end{array}$ & $\begin{array}{c}\text { Justice, and job } \\
\text { satisfaction }\end{array}$ \\
\hline 34 & $\begin{array}{c}\text { Madera et } \\
\text { al.(2016) }\end{array}$ & Ethnic groups & $\begin{array}{c}\text { Justice } \\
\text { theory,Social } \\
\text { identity } \\
\text { theory }\end{array}$ & $\begin{array}{l}\text { Frontline } \\
\text { managers }\end{array}$ & USA & 164 & $\begin{array}{c}\text { survey } \\
\text { statistical } \\
\text { analysis }\end{array}$ & Job satisfaction \\
\hline 35 & $\begin{array}{l}\text { Guchait et } \\
\text { al. (2016) }\end{array}$ & $\begin{array}{c}\text { Racioethnic } \\
\text { minority } \\
\text { status }\end{array}$ & $\begin{array}{l}\text { Racial identity } \\
\text { theory }\end{array}$ & $\begin{array}{l}\text { Frontline } \\
\text { managers }\end{array}$ & USA & 164 & $\begin{array}{c}\text { survey } \\
\text { statistical } \\
\text { analysis }\end{array}$ & $\begin{array}{c}\text { Justice, and job } \\
\text { satisfaction }\end{array}$ \\
\hline
\end{tabular}




\begin{tabular}{|c|c|c|c|c|c|c|c|c|}
\hline NO: & $\begin{array}{c}\text { Source } \\
\text { Title }\end{array}$ & Dimension & Theory & $\begin{array}{c}\text { Unit of } \\
\text { Analysis }\end{array}$ & Country & $\begin{array}{c}\mathrm{N} \text { of } \\
\text { sample }\end{array}$ & Methodogy & Outcomes \\
\hline 36 & $\begin{array}{c}\text { Hennekam } \\
\text { and Ladge } \\
\text { (2017) }\end{array}$ & $\begin{array}{c}\text { Lesbian } \\
\text { Motherhood } \\
\text { Pregnancy }\end{array}$ & $\begin{array}{c}\text { Stigma } \\
\text { theory,Gender } \\
\text { role theory }\end{array}$ & $\begin{array}{l}\text { Lesbian } \\
\text { couples }\end{array}$ & Netherlands & 14 & $\begin{array}{c}\text { semi- } \\
\text { structured } \\
\text { in-depth } \\
\text { interviews }\end{array}$ & Stigma \\
\hline 37 & $\begin{array}{c}\text { Buttner } \\
\text { and Lowe } \\
\text { (2017) }\end{array}$ & Race & $\begin{array}{c}\text { Stakeholder } \\
\text { theory, Social } \\
\text { Identity } \\
\text { Theory, Equity } \\
\text { Theory }\end{array}$ & $\begin{array}{c}\text { Business } \\
\text { school faculty } \\
\text { professional }\end{array}$ & USA & 182 & $\begin{array}{l}\text { survey } \\
\text { statistical } \\
\text { analysis }\end{array}$ & $\begin{array}{l}\text { Corporate social } \\
\text { responsibility, } \\
\text { Perceived pay } \\
\text { equity, Turnover } \\
\text { intentions }\end{array}$ \\
\hline 38 & $\begin{array}{l}\text { Sukoco } \\
\text { and Lee } \\
(2017)\end{array}$ & $\begin{array}{l}\text { Diversity } \\
\text { climate }\end{array}$ & $\begin{array}{l}\text { Attribution } \\
\text { theory }\end{array}$ & $\begin{array}{l}\text { New product } \\
\text { development } \\
\text { (NPD) teams }\end{array}$ & Taiwan & 375 & $\begin{array}{c}\text { survey } \\
\text { statistical } \\
\text { analysis }\end{array}$ & $\begin{array}{c}\text { Psychological } \\
\text { capital, product } \\
\text { innovation }\end{array}$ \\
\hline 39 & $\begin{array}{l}\text { Paolillo et } \\
\text { al. (2017) }\end{array}$ & $\begin{array}{l}\text { Women and } \\
\text { minorities }\end{array}$ & $\begin{array}{c}\text { Social identity } \\
\text { theory, } \\
\text { Cultural } \\
\text { diversity } \\
\text { model }\end{array}$ & $\begin{array}{l}\text { White and } \\
\text { blue-collar } \\
\text { employees }\end{array}$ & Italia & 395 & $\begin{array}{c}\text { interview, } \\
\text { statistical } \\
\text { analysis }\end{array}$ & $\begin{array}{c}\text { Mor Barak } \\
\text { diversity climate } \\
\text { scale found } \\
\text { reliable }\end{array}$ \\
\hline 40 & $\begin{array}{l}\text { Vargas et } \\
\text { al. }(2018)\end{array}$ & $\begin{array}{c}\text { Race } \\
\text {,composite } \\
\text { Seniority, } \\
\text { Sex, age }\end{array}$ & Signal theory & Academics & USA & 35029 & $\begin{array}{l}\text { survey } \\
\text { statistical } \\
\text { analysis }\end{array}$ & $\begin{array}{c}\text { Job productivity, } \\
\text { stress, job } \\
\text { dissatisfaction }\end{array}$ \\
\hline 41 & $\begin{array}{l}\text { Moon } \\
(2018)\end{array}$ & $\begin{array}{c}\text { Gender, race, } \\
\text { and age }\end{array}$ & $\begin{array}{c}\text { Social } \\
\text { interactions } \\
\text { theory }\end{array}$ & Employees & USA & 396 & $\begin{array}{c}\text { survey } \\
\text { statistical } \\
\text { analysis }\end{array}$ & $\begin{array}{c}\text { Organizational } \\
\text { social capital }\end{array}$ \\
\hline
\end{tabular}

